\title{
FLUCTUATIONS OF THE VESTFONNA ICE MARGIN \\ AT BRAGENESET, NORDAUSTLANDET, SVALBARD, AFTER THE LAST \\ GLACIAL MAXIMUM
}

\author{
J.J.DONNER and R.G.WEST
}

DONNER, J.J. and WEST, R.G. 1995. Fluctuations of the Vestfonna ice margin at Brageneset, Nordaustlandet, Svalbard, after the last glacial maximum. Bull. Geol. Soc. Finland 67, Part I, 29-36.

Four radiocarbon datings of shells of Mya truncata and Saxicava arctica from the till of the end-moraine of the advance of Vestfonna against Brageneset, Nordaustlandet, between AD 1861 and 1899, gave ages between $8300 \mathrm{BP}$ and $8700 \mathrm{BP}$. These are from the time when the ice margin had retreated from Brageneset after the last glaciation. An additional age of $7900 \mathrm{BP}$ obtained for Astarte elliptica, also from the end-moraine, shows that the shells in the till represent a mixed death assemblage, as also shown by the composition of the molluscan fauna in general. By comparing the altitudes of the two pumice levels with their altitudes in other areas of Svalbard a curve for the relative uplift of Brageneset could be constructed. According to this curve the highest point of Brageneset at $46.5 \mathrm{~m}$ emerged at about $9200 \mathrm{BP}$, which gives a minimum age for the general deglaciation, an age in agreement with dates obtained from other parts of Nordaustlandet.

Key words: glaciation, deglaciation, uplifts, till, mollusks, shells, C-14, Holocene, Nordaustlandet, Svalbard.

J.J.Donner: Department of Geology, P.O.Box 11 , FIN - 00014, University of Helsinki, Finland

R.G.West: Subdepartment of Quaternary Research, Department of Plant Sciences, University of Cambridge, Downing Street, Cambridge CB2 3EA, U.K. 


\section{INTRODUCTION}

Brageneset, situated almost $80^{\circ} \mathrm{N}$, is a promontory with a base about $5 \mathrm{~km}$ long against the south-western margin of Vestfonna (West Ice) on Nordaustlandet (North East Land) and extends about $3 \mathrm{~km}$ into the Hinlopenstretet (Hinlopen Strait) separating Nordaustlandet from Spitsbergen (Fig. 1). The surface of Brageneset, which reaches an altitude of $46.5 \mathrm{~m}$ in its western part, is composed of outcrops of weathered dolerite surrounded by a series of raised beach shingle bars and terraces. The thin beach deposits mantle the till found in the depressions between the dolerite outcrops. All sediments have been affected by frost action as witnessed by ground polygons and frost-cracks on level ground and stone stripes on sloping ground. The edge of the lobe of Vestfonna sloping against Brageneset shows lines of till brought to the surface in thrustplanes, but in the north-eastern parts of Brageneset there is a fresh hummocky end-moraine formed during an advance and standstill of Vestfonna. This end-moraine was outside the ice margin in the summer of 1955 when Brageneset (Fig. 1) was studied by Donner and West (1957). The end-moraine was partly surrounded by an ice-dammed lake, and in addition there were two smaller lakes between the ice margin and the foreland. In contrast to the sloping edge of the ice margin at Brageneset, Vestfonna forms steep calving cliffs where it faces the sea on each side of the promontory, these cliffs having in places nearly vertical thrustplanes with till.

Vestfonna was classified by Glen (1941) as a sub-arctic glacier cap with its surface features controlled by the underlying subglacial topography. The nunataks and the surface configuration of the glacier suggest, according to Glen, that the marginal zones of the glacier cap rarely exceed $50 \mathrm{~m}$ in thickness, an estimate in general agreement with electro-thermic drilling results from the marginal area of Vestfonna near Brageneset in 1955 (Hollin, 1956). Furthermore, Glen concluded that where the ice ends in a cliff it is not more than $20 \mathrm{~m}$ thick, even in areas facing the sea and that most of it is aground. This would mean that the ice cliffs on each side of
Brageneset are aground and that the subglacial surface is not far below sea-level, as is also indicated by the section of Vestfonna drawn by Glen (1941) over the glacier cap to Brageneset (Cape Brage). The thickness of the Vestfonna ice was suggested by Glen to be thicker, at most 300 $\mathrm{m}$, only in the subglacial valleys. In discussing the terminal moraine of the present ice margin Glen concluded that the material in this moraine was a thin "surface scraping" originating subglacially, and that since the formation of the moraine Vestfonna has become dynamically inactive, with a thinning of the glacier cap as a result, without any major retreat of its edge. The observations published by Glen (1941) were made in 1935-36.

The age of the glacier advance which resulted in the formation of the fresh end-moraine on Brageneset can be estimated on the basis of the observations made in the area at different times, as summarised by Donner and West (1957). On the map published by Dunér and Nordenskiöld (1865) Brageneset was an island named Hyperitön. The map was based on observations made by Nordenskiöld when he landed on the island in 1861. Brageneset was similarly an island on the map published by van Keulen in about 1710 (see Donner and West, 1957). But, on the other hand, Brageneset was a promontory outside Vestfonna on the map produced by a Russo-Swedish expedition in 1899-1902 (De Geer, 1923). Thus the ice advance took place between 1861 and 1899. Since the formation of the young moraine there has been a recession of the ice margin, especially in the north-western part of Brageneset, as seen by comparing the ice margin on aerial photographs from 1923 with its position in 1955 (Donner and West, 1957).

In contrast to the beach sediments, which are generally unfossiliferous, the till on Brageneset is shelly, which shows that the ice over-rode marine deposits before depositing the till. Shell samples were collected in 1955 from seven sites by Donner and West (1957), all except one sample being from the marginal zone of Vestfonna. Several shell species were identified and listed by Donner and West; the shells were generally well preserved and unbroken 


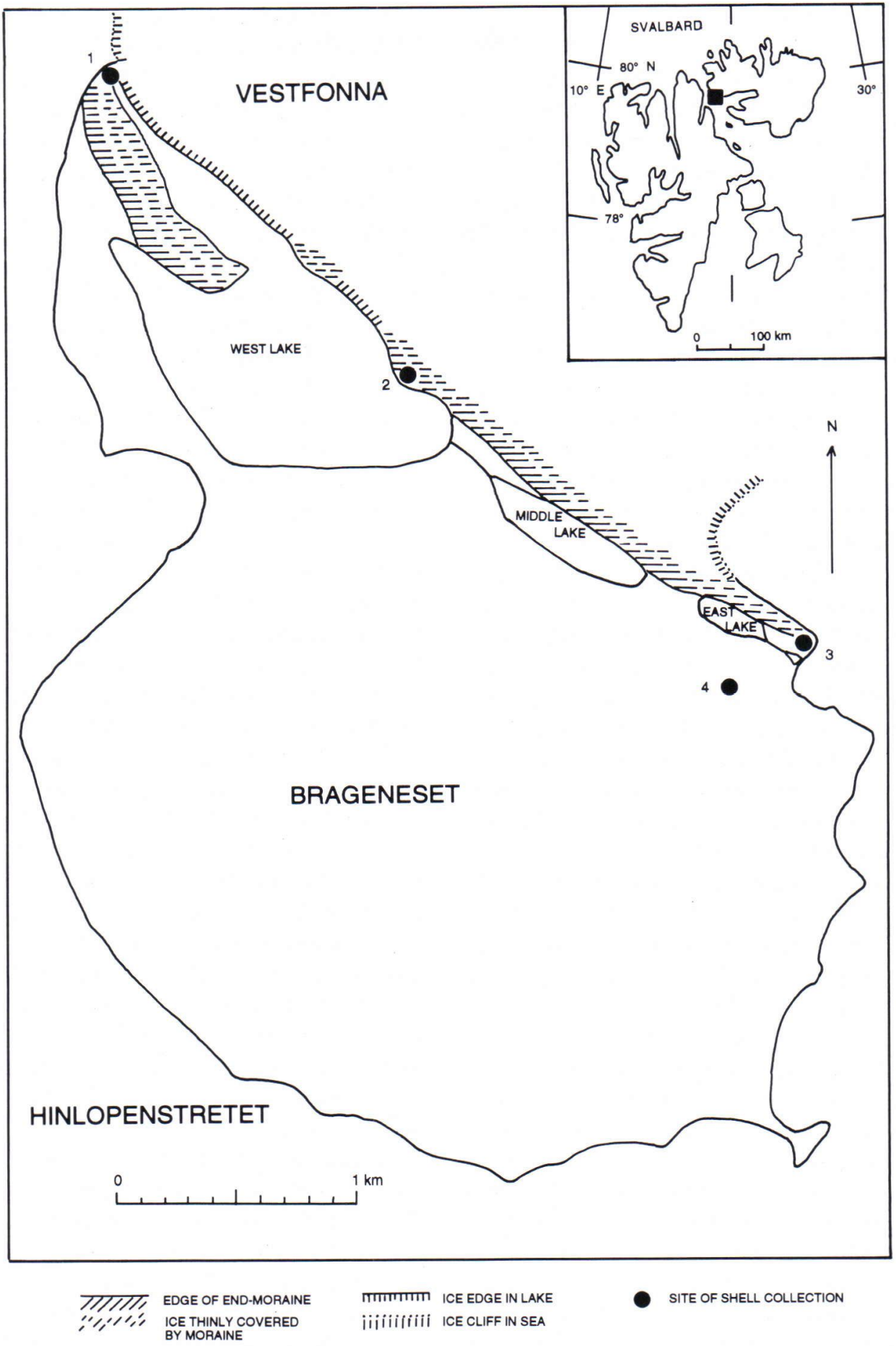

Fig.1. Map of Brageneset (based on Fig.2 in Donner and West, 1957) with sites for dated shells. 
in the till of the marginal ice. Many of the shell species were rare or were found only occasionally in the samples, but Saxicava (Hiatella) arctica and Mya truncata were abundant in all samples. As there are no previous radiocarbon dates from Brageneset five samples of shells collected in 1955 were dated in the Dating Laboratory of the University of Helsinki in order to determine the age relationship between the young end-moraine, formed between 1861 and 1899, and the marine sediments from the time before the ice advance, when Brageneset was an island. At the same time the ages could be used for estimating the age of the deglaciation after the last glacial maximum.

\section{RADIOCARBON AGES}

Three shell samples of Mya truncata were dated from the till of the young end-moraine, one sample from each end of the about $5 \mathrm{~km}$ long moraine and one from about half-way between them, as shown in Figure 1. The fourth sample was of Saxicava arctica from the surface of the till just outside the moraine in its south-eastern part. The fifth sample was of Astarte elliptica from the southeastern end of the moraine, from the same site from which one of the samples of Mya truncata was dated. The radiocarbon ages and $\delta^{13} \mathrm{C}$ values (o/oo PDB) determined for the shells are listed in Table 1 . The radiocarbon ages given as years $\mathrm{BP}$ were normalized to the $\delta^{13} \mathrm{C}$ value of $-25 \mathrm{o} / \mathrm{oo}$. To make the ages comparable with ages used in Svalbard generally (Mangerud et al., 1992) a reservoir age of 440 years was subtracted from the dates and given as corrected ages. These were then used in the following and also shown in Figure 1.

\section{CONCLUSIONS}

The radiocarbon ages alone show that Brageneset was deglaciated at the latest by about $8800 \mathrm{BP}$ and that the marine shells dated were deposited northeast of Brageneset when it was an island emerging from the sea. The position of the margin of Vestfonna between the deglaciation and its young advance between 1861 and 1899 is not known but, as noted before, Brageneset was an island before 1861 and also in 1710 . The advance picked up the shells, including those dated at 8300-8700 BP and 7900 BP, from marine sediments near Brageneset and incorporated them into the till of the young end-moraine, without damaging or breaking the shells. As the shells dated were not only from the morphologically well defined young end-moraine (Sites 1-3), but also from just outside it (Site 4), the advance between 1861 and 1899 must have extended somewhat beyond the present position of the ice margin also in the south-eastern part of Brageneset, as it did in the north-western part. It does not seem possible that an earlier ice advance would have deposited a shelly till at Site 4 with shells of practically the same age as the shells in the till of the young advance.

The grouping of the radiocarbon ages of $M y a$ truncata and Saxicava arctica around 8300-8700 BP and the age of 7900 BP for Astarte elliptica can best be explained by viewing them against the deglaciation and emergence history of Brageneset

Table 1. Shell dates from Brageneset. Site numbers used by Donner and West (1957) in brackets

Site 1(1) Mya truncata

Site 2(3) Mya truncata

Site 3(5) Mya truncata

Site 3(5) Astarte elliptica

Site 4(6) Saxicava arctica

$$
\begin{aligned}
& 9180 \pm 150 \text { BP Hel-3289 } \delta^{13} \mathrm{C}+1.9 \text { corr. age } 8740 \pm 150 \text { BP } \\
& 8760 \pm 170 \text { BP Hel-3290 } \delta^{13} \mathrm{C}+1.9 \text { corr. age } 8320 \pm 170 \text { BP } \\
& 8820 \pm 140 \text { BP Hel-3291 } \delta^{13} \mathrm{C}+2.0 \text { corr. age } 8380 \pm 140 \mathrm{BP} \\
& 8340 \pm 120 \mathrm{BP} \text { Hel-3577 } \delta^{13} \mathrm{C}+1.7 \text { corr. age } 7900 \pm 120 \mathrm{BP} \\
& 9060 \pm 140 \mathrm{BP} \text { Hel-3396 } \delta^{13} \mathrm{C}+0.5 \text { corr. age } 8620 \pm 140 \mathrm{BP}
\end{aligned}
$$


and by taking into account the composition of the shell assemblages found in the till of the young endmoraine. Subsequent to the deglaciation of Brageneset before $8800 \mathrm{BP}$, which is the oldest age of shells at Site 1, there was a rapid isostatic rebound of Brageneset which was totally submerged when it became ice-free, as seen from the beach deposits. The emergence of Brageneset has not been dated, but as the two pumice levels identified on Brageneset (Donner and West, 1957) have been identified and dated elsewhere in Spitsbergen where the relative uplift has been studied in detail, a curve for the uplift could be constructed also for Brageneset. The upper pumice level, which is at $13.8 \mathrm{~m}$ on Brageneset, has been found at a number of sites in both Spitsbergen and Nordaustlandet and dated at 6500 BP (Boulton and Rhodes, 1974; Salvigsen, 1981, 1984; Österholm, 1988). The lower pumice level, at $6.4 \mathrm{~m}$ on Brageneset, has similarly been dated at about 4500 BP (Salvigsen, $1978,1981,1984)$. In addition to the two abovementioned levels pumice was recorded from other lower levels on Kong Karls Land south-east of Nordaustlandet (Salvigsen, 1981).

In Figure 2 a curve for the relative uplift of Brageneset was constructed by using the dates for the two pumice levels and by using three dated curves constructed for other parts of Spitsbergen. The uppermost curve is for Billefjorden in the inner part of Isfjorden in the western part of Spitsbergen, which was deglaciated about 10,000 years ago (Salvigsen, 1984). Of the two lowermost curves the upper one is for Valhallafonna in the north-eastern part of Spitsbergen, at Hinlopenstretet opposite Brageneset (Boulton and Rhodes, 1974), and the lower curve for the Murchisonfjorden - Lady Franklinfjorden area in north-western Nordaustlandet (Olsson and Blake, 1962). When the curve for Brageneset is drawn to conform with the three other curves it reaches the highest level of Brageneset at $46.5 \mathrm{~m}$ at about 9200 BP. This means that Brageneset must have been deglaciated before this date, before the time indicated by the oldest shell dates.

The shell assemblages in the till of the young ice advance against Brageneset represent 16 shell species, of which the shells of Mya truncata and Saxicava arctica are the only abundant ones, the former most common of all (Donner and West, 1957). As the shells were picked up from marine deposits by the ice during the advance between 1861 and 1899 the shells represent a mixed death assemblage of shells from the time when the sea separated Brageneset from Vestfonna, a period of nearly 9000 years. It is possible that there were some fluctuations of the ice margin in this time, but there is no evidence of an advance over Brageneset between the time of the early deglaciation and the young advance at the end of the last century. Because of the changes in climate and water temperature during this time there were changes in the composition of the fauna and some species immigrated into the area around Brageneset after the deglaciation later than others. Because of the scarcity of shells only those of Astarte elliptica, in addition to the shells of Mya truncata and Saxicava arctica, could be dated separately. By making comparisons with an area in which the marine fossil fauna is known in detail some conclusions can be drawn about the molluscan fauna found in the till of Brageneset. A suitable area is Billefjorden in the inner part of Isfjorden on the west coast of Spitsbergen (Feyling-Hanssen, 1955).

The coasts of Hinlopenstretet around Brageneset, as all coasts of Nordaustlandet, are in the high-arctic subregion of the arctic province in the division used in the description of the distribution of the marine molluscs (Feyling-Hanssen, 1955). Billefjorden is in the mid-arctic subregion and some species are therefore found in the latter area which have not been recorded from Brageneset. Of the 9 species of Bivalves recorded from the till on Brageneset, 8 were also recorded from Billefjorden, and of 7 Gastropods 6 were also recorded from Billefjorden. In the division of the marine stratigraphy of the littoral and sublittoral molluscs below the marine limit at $85 \mathrm{~m}$ in Billefjorden, Feyling-Hanssen (1955) separated an initial Late-Glacial Cold Period. In the sediments of this period only scattered shells of the two species Mya truncata and Saxicava arctica were found. In the sublittoral sediments lower down, representing the Post-Glacial 


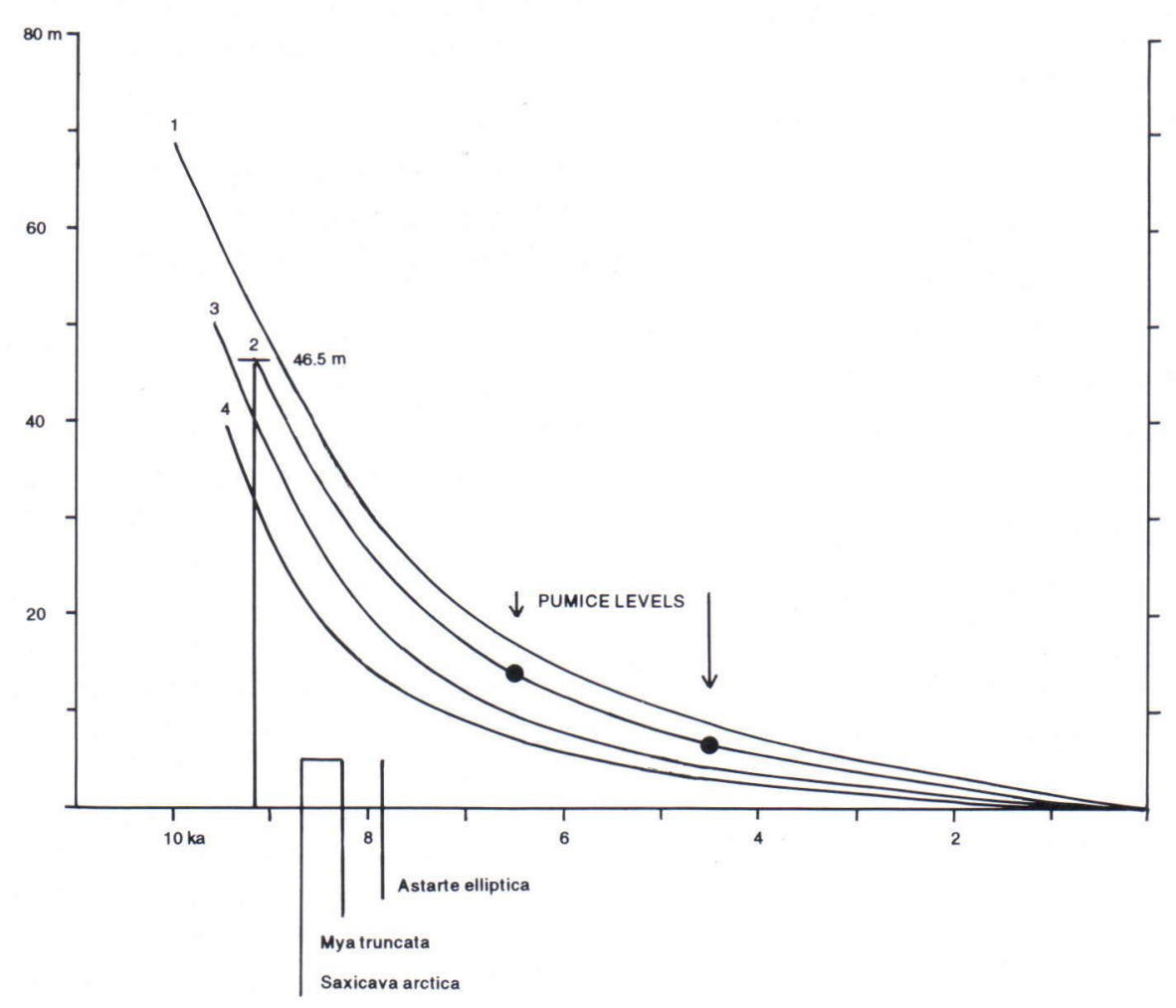

Fig.2. Curves for relative uplift in 1, Billefjorden, Spitsbergen (Salvigsen, 1984); 3, Valhallafonna, Spitsbergen (Boulton and Rhodes, 1974); 4, Murchisonfjorden and Lady Franklinfjorden, Nordaustlandet (Olsson and Blake, 1962), and a curve constructed for Brageneset, 2, with the two pumice levels identified. Range of ages for Mya truncata and Saxicava arctica and the age of Astarte elliptica are also included.

Temperate Period, Mya truncata dominates, but with a strong representation of Macoma calcarea and Saxicava arctica. If the Billefjord stratigraphy is taken into account in the interpretation of the results from Brageneset it can be assumed, by analogy, that Mya truncata and Saxicava arctica together represent the first molluscan fauna which invaded the sea around Brageneset after the deglaciation (Fig.2). After the predominance of these two species other mollusc species spread into the area, such as Astarte elliptica. There was thus a succession of new species spreading into the coastal waters and the shells of all these species were included into the mixed death assemblage of the till in the young end-moraine at Brageneset. The shell species recorded both from the till of the young ice advance on Brageneset and from Billefjorden are listed in Table 2 in the order in which they immigrated into the latter area (Feyling-Hanssen, 1955). The age of Astarte elliptica from Brageneset shows, however, that it immigrated earlier than the results from Billefjorden would indicate. The two species found on Brageneset but not in Billefjorden were Leda minuta Müller and Trichotropis borealis Broderip and Sowerby (Donner and West, 1957).

As Mya truncata and Saxicava arctica have been present in Spitsbergen since the time of deglaciation the ages of between about $8300 \mathrm{BP}$ 
Table 2. Shells found at Brageneset listed in the order of immigration in Billefjorden according to Feyling-Hanssen (1955)

Mya truncata (Linné)
Saxicava arctica (Linné)
Macoma calcarea (Chemnitz)
Chlamys islandica (Müller)
Serripes groenlandicus (Chemnitz)
Lepeta coeca (Müller)
Astarte borealis (Chemnitz)
Astarte montagui (Dillwyn)
Astarte elliptica (Brown)
Puncturella noachina (Linné)
Trophon truncatus (Ström)
Buccinum glaciale (Linné)
Natica clausa (Broderip and Sowerby)

and $8700 \mathrm{BP}$ obtained from Brageneset for these two species may have been affected by younger shells mixed into the assemblage representing the time shortly after deglaciation when the two species were predominant. But as the ages are rather uniform, spanning a period of only about 400 years, this effect is probably relatively small. The younger age of $7900 \mathrm{BP}$ for Astarte elliptica confirms that the shells in the till on Brageneset represent a mixed death assemblage, even if the age difference between Astarte elliptica and the two other species is only 400-800 years. It can be assumed that in addition to the ages obtained for the three shell species from Brageneset (Figs 1 and 2) the ages of the shells of other species are different, in between the age of nearly 9000 BP and the time of the young ice advance. The shallowing of the waters around Brageneset as a result of the uplift following deglaciation may, however, partly have prevented shell accumulation during the last few thousand years. This would have resulted in an absence of younger redeposited shells in the young end-moraine.

\section{COMPARISON OF THE GLACIAL HISTORY ON BRAGENESET WITH THAT IN OTHER PARTS OF SVALBARD}

The constructed curve for the relative uplift of Brageneset gives a minimum age of $9200 \mathrm{BP}$ for the deglaciation after the last glacial maximum, before the young ice advance between 1861 and 1899 pushed against the north-eastern part of Brageneset. From the summary of the minimum ages for the last deglaciation in Svalbard by Mangerud et al. (1992) it can be seen that the ages obtained from Nordaustlandet are between 9600 $\mathrm{BP}$ and 10,000 BP, whereas some ages from the outer coast of the western parts of Spitsbergen are over 12,000 BP (see also Svendsen and Mangerud, 1992). The ages from the western parts of Nordaustlandet along Hinlopenstretet, including the inner part of Wahlenbergfjorden, vary between $9600 \mathrm{BP}$ and 10,800 BP. As some of these ages are from areas not immediately outside the present outer margin of Vestfonna or Sørfonna further south, these ages can be expected to be slightly older than the age of 9200 BP for Brageneset, which is a minimum age and is likely to be somewhat older. By constructing the curve for the relative uplift of Brageneset (Fig.2) it was assumed that it is similar to the curves for other areas of Spitsbergen, as there is no reason to believe that the emergence of Brageneset would have been irregular.

The ice advance of Vestfonna against Brageneset between 1861 and 1899 is similar in nature to other local advances in Svalbard described as surges. The observations made by Gerard De Geer in 1908 and 1910 and later studies by van der Meer (1992) showed that there was a surge of Sefströmbreen in Ekmansfjorden in the inner part of Isfjorden on the west coast of Spitsbergen between 1882 and 1896, after which there was a retreat of several kilometres already between 1896 and 1908. The surge deposited sediments 
with shells from the fjord bottom on Coraholmen at the front of the glacier, similarly as the Vestfonna ice deposited the shelly till on Brageneset. The demonstration of an earlier surge of Sefströmbreen confirmed that surging is a recurrent feature in the behaviour of glaciers (van der Meer, 1992). A comparatively extensive surge took place in the southern part of Nordaustlandet when Bråsvellbreen of Sørfonna surged into the sea in two years, 19361938 (Thompson, 1953). Since then the ice margin has retreated, nearly $1 \mathrm{~km}$ up till 1949 . There was a general regrowth of glaciers in Svalbard in the last century (Svendsen and Mangerud, 1992) and a subsequent retreat. Franklin Glacier in the northern part of Vestfonna had, for instance, retreated about 3 km since 1900 when studied by Glen (1941), and

\section{REFERENCES}

Boulton, G.S. and Rhodes, M. 1974. Isostatic uplift and glacial history in northern Spitsbergen. Geological Magazine 111(6), 481-576.

De Geer, G. 1923. Mission Suédoise pour la Mesure d'un Arc de Méridien au Spitzberg: Vol. 2, pt. 9, Topographie et Geologie. Stockholm.

Donner, J.J. and West, R.G. 1957. The Quaternary geology of Brageneset, Nordaustlandet, Spitsbergen. Norsk Polarinstitutt. Skrifter 109.

Dunér, N. and Nordenskiöld, A.E. 1865. Anteckningar till Spetsbergens geografi. Kungliga Svenska Vetenskapsakademiens Handlingar 6(5).

Feyling-Hanssen, R.W. 1955. Stratigraphy of the marine Late-Pleistocene of Billefjorden, Vestspitsbergen. Norsk Polarinstitutt. Skrifter 107.

Glen, A.R. 1941. A Sub-Arctic glacier cap: the West Ice of North East Land. The Geographical Journal 98(2), 65-76, 135-146.

Hollin, J.T. 1956. Oxford University Expedition to Nordaustlandet, 1955. The Polar Record 8(52), 26.

Mangerud, J., Bolstad, M., Elgersma, A., Helliksen, D., Landvik, J.Y., Lonne, I., Lycke, A.K., Salvigsen, O., Sandahl, T. and Svendsen, J.I. 1992. The last glacial maximum on Spitsbergen, Svalbard. Quaternary Research 38, 1-31.

Meer, J.J.M. van der, 1992. The De Geer Archive in Stockholm exemplified by the documentation on a latenineteenth century glacier surge in Spitsbergen. Sveriges Geologiska Undersökning, Series Ca 81, 187-194. the glacier in Brandy Bay further north about 1.5 $\mathrm{km}$ in 75 years since 1865 . These examples show that there was not just one ice advance during the Little Ice Age, glaciologically defined as covering approximately the period between 1500 and 1920 (Sugden and John, 1979), but several local surges at different times. The timing of older surges is not known.

ACKNOWLEDGEMENTS: The authors are grateful to $D r$. Högne Jungner for the radiocarbon dating of the shell samples in the Dating Laboratory of the University of Helsinki.
Olsson, I. and Blake, W. Jr. 1962. Problems of radiocarbon dating of raised beaches, based on experience in Spitsbergen. Norsk Geografisk Tidsskrift 18(1-2), 1-18.

Österholm, H. 1988. Raised beaches and crustal uplift on Prins Oscars Land, Noraustlandet, Svalbard. Department of Physical Geography, Forskningsrapport STOU NG 69.

Salvigsen, O. 1978. Holocene emergence and finds of pumice, whalebones, and driftwood at Svartnausflya, Nordaustlandet. Norsk Polarinstitutt. Årbok 1977, 217 228.

Salvigsen, O. 1981. Radiocarbon dated raised beaches in Kong Karls Land, Svalbard, and their consequences for the glacial history of the Barents Sea area. Geografiska Annaler 63 A (3-4), 283-291.

Salvigsen, O. 1984. Occurrence of pumice on raised beaches and Holocene shoreline displacement in the inner Isfjorden area, Svalbard. Polar Research 2 n.s., 107-113.

Sugden, D.E. and John, B.S. 1979. Glaciers and landscape. Edward Arnold, London.

Svendsen, J.I. and Mangerud, J. 1992. Paleoclimatic inferences from glacial fluctuations on Svalbard during the last 20000 years. Climate Dynamics 6, 213-220.

Thompson, H.R. 1953. Geology and geomorphology in southern Nordaustlandet (North-East Land), Spitsbergen. Proceedings of the Geologists' Association 64(4), 293-312. 